УДК 378:37.011.3

DOI:

Світлана Яців, кандидат педагогічних наук, доиент кафедри англійської філологї ДВНЗ “Прикарпатський національний університет імені Василя Стефаника"

Юлія Веляник, студентка ДВНЗ “Прикарпатський національний університет імені Василя Стефаника”

\title{
КОМУНІКАТИВНО-РИТОРИЧНИЙ АСПЕКТ ПІДГОТОВКИ МАЙБУТНЬОГО ВЧИТЕЛЯ АНГЛІЙСЬКОӤ МОВИ
}

Стаття присвячена проблемі підготовки майбутнього вчителя англійської мови. Автори вагоме місие в ивому процесі відводять комунікативній підготовці. Саме комунікативно-риторичні вміння як важливий складник загальної і професійної культури педагога допоможуть учителеві англійської мови, окрім іншого, ефективно організовувати педагогічний процес, будувати переконливу комунікацію з дітьми, їхніми батьками, колегами, громадськістю тощо. У структурі комунікативно-риторичних умінь виокремлено три взаємопов'язані компоненти (мисленнєвий, мовленнєвий, комунікативний). Вимоги до професії майбутнього вчителя англійської мови передбачають наявність у фахівия відповідних умінь для ефективного забезпечення ії комунікативно-риторичних аспектів. Ці вміння мають свою специфіку, що зумовлюється метою, завданнями, об 'єктами, сферами застосування та функиіями його професійної діяльності.

Ключові слова: майбутні вчителі англійської мови; комунікативно-риторичні уміння; професійна підготовка; мовна компетентність.

Jim. 6.

Svitlana Yatsiv, Ph.D.(Pedagogy), Associate Professor of the English Philology Department, SHEI "Vasyl Stefanyk Precarpathian National University"

Juliia Velianyk, Student, SHEI "Vasyl Stefanyk Precarpathian National University"

\section{COMMUNICATIVE AND RHETORICAL ASPECT OF A FUTURE ENGLISH TEACHER TRAINING}

The article is devoted to the issue of a future English teacher training. According to the authors, the communicative training has an important place in this process. It is the communicative and rhetorical skills as an important component of general and professional culture of the teacher that, among other things, will help the English teacher to organize the pedagogical process effectively, build persuasive communication with children, their parents, colleagues, society etc. In the structure of communicative and rhetorical skills there are three interrelated elements (mental, verbal, communicative). The requirements of the profession of future English teacher suppose that the specialist has the appropriate skills to effectively ensure its communicative and rhetorical aspects. These skills have their own specifics, which are determined by the purpose, tasks, objects, scope of application and functions of his/her professional activity.

The formation of communicative and rhetorical skills of future English teachers in the system of higher education is an important component of improving the quality of training, because inability to carry on a constructive dialogue, to debate, to talk, to give a speech, expressing your own view on the problem of the present time makes the pedagogical process to slow down. Communicative and rhetorical skills are an important tool for organizing of his/ her practical activities in the structure of English teacher professional training.

Now it is time for rhetoric training process of future teachers of English, including the ensuring of professional and pedagogical orientation of the content of education, intensification of educational and rhetorical activities of students, increasing practical training, formation of communicative and rhetorical skills together with mental, verbal and communicative elements, organization of effective individual students' work, establishing interdisciplinary links with other disciplines which can contribute to the formation and improvement of these skills.

Keywords: future English teachers; communicative and rhetorical skills; professional training; linguistic competence.

П

остановка проблеми. Сучасні тенденції в розвитку системи вищої педагогічної освіти вимагають постійного перегляду концептуальних i технологічних підходів до підготовки педагогічних кадрів. Гуманізація, гуманітаризація освіти, ідеї особистісної та соціальної орієнтованості у вищій педагогічній освіті, шляхи формування активної особистості, здатної самостійно робити вибір, ставити і реалізовувати цілі, що виходять за межі, визначені освітніми стандартами, усвідомлено оцінювати свою діяльність - ось ті пріоритети, які визначають концептуальні положення педагогічної освіти, що випливають з Концепції 


\section{КОМУНІКАТИВНО-РИТОРИЧНИЙ АСПЕКТ ПІДГОТОВКИ МАЙБУТНЬОГО ВЧИТЕЛЯ АНГЛЙСЬКОӤ МОВИ}

Нової української школи, новітніх освітніх документів. Вагоме місце в підготовці вчителя нового покоління теоретики і практики відводять комунікативній підготовці. Саме комунікативні вміння як важливий складник загальної і професійної культури педагога допоможуть учителеві англійської мови, окрім іншого, ефективно організовувати педагогічний процес, будувати переконливу комунікацію $з$ дітьми, їхніми батьками, колегами, громадськістю тощо. Ці професійні вміння необхідні педагогові, позаяк спілкування, слово - це його основні інструменти в діяльності.

Аналіз останніх досліджень і публікацій. Проблему підготовки до професійної діяльності досліджували О. Абдуліна, Ф. Гоноболін, М. Євтух, В. Крутецький, 3. Курлянд, Н. Тализіна та ін.; риторична культура особистості майбутнього фахівця була в центрі уваги Г. Білавич, Н. Голуб, І. Звєревої, А. Капської, Г. Онуфрієнко, Г. Сагач та ін.; питання підготовки майбутніх учителів англійської мови вивчали О. Бігич, О. Бондаренко, І. Максак, С. Ніколаєва, В. Плахотник, С. Роман та ін., однак окремі аспекти професійної підготовки фахівців англійської мови, зокрема комунікативно-риторичний аспект вектор їхньо мовної компетентності, залишаються недостатньо висвітленими в науковій літературі.

Мета статті - обгрунтувати комунікативнориторичний аспект підготовки майбутнього вчителя англійської мови як складник його мовної компетентності.

Виклад основного матеріалу. Професійну компетентність науковці трактують як здатність фахівця від початку своєї професійної діяльності на рівні визначеного державою стандарту відповідати суспільним вимогам професії завдяки здійсненню ефективної професійної діяльності та демонструвати належні особистісні якості, мобілізуючи для цього відповідні знання, уміння, навички, емоції, грунтуючись на внутрішній мотивації, ставленнях, моральних та етичних цінностях і досвіді, усвідомлюючи обмеження своїх знань та акумулюючи інші ресурси для їх компенсації тощо [3; 5]. Чільне місце в підготовці вчителя англійської мови посідає мовна компетентність. Відтак формування комунікативнориторичних умінь майбутніх учителів англійської мови в процесі їхньої професійної підготовки у закладі вищої освіти вважаємо важливим складником їхньої професійної компетентності, підвищення ефективності фахової діяльності.

За результатами нашого аналізу стану наукової літератури $з$ порушеної проблеми уважаємо: дослідники недостатньо уваги присвятили проблемам формування комунікативнориторичної особистості майбутнього вчителя англійської мови.

Згідно 3 вимогами Загальноєвропейських Рекомендацій 3 мовної освіти, майбутні педагоги повинні вміти: висловлювати свою точку зору з певної проблеми; готувати публічні виступи з певних фахових питань, застосовуючи засоби вербальної комунікації та адекватні форми ведення дискусії та дебатів; зважувати позитивн та негативні аспекти проблеми; використовувати комунікативні стратегії задля підтримання розмови 3 певної теми; підтримувати чи спростовувати аргумент/думку; підсумовувати, отримувати інформацію і коментувати її; підтримувати розмову без попередньої підготовки; розуміти і реагувати на повідомлення загального характеру та з метою отримання спеціальної інформації у текстах таких типів: інтерв'ю, короткі навчальні бесіди, новини тощо [2].

Подібні вимоги окреслені у "Плані дій щодо створення єдиного європейського індикатора провідних компетентностей" (The European Indicator of Language Competence) [6], де актуалізовано лінгвістичну компетентність (система внутрішньо засвоєних комунікантом знань щодо функціонування іноземної мови, що виявляється у їх використанні в мовленнєвій діяльності); соціальну компетентність (охоплює соціокультурний, соціолінгвістичний і професійний складники, які сприяють реалізації основної мети сучасної освіти, коли іноземна мова постає засобом соціокультурного розвитку особистості, збагачення знаннями нової культури); комунікативну компетентність (володіння властивими кожному висловлюванню правилами, які підпорядковуються загальним правилам граматики, що забезпечує здатність використання мови в процесі комунікації) [6].

3-поміж завдань Концепції "Нова українська школа" - ухвалення нових стандартів загальної середньої освіти, розроблених з урахуванням компетентностей, необхідних для успішної самореалізації особистості [4], де іншомовна комунікативна компетентність посідає чільне місце.

Аналіз стану підготовки студентів у більшості закладів вищої освіти засвідчує: досі відсутня перспективна концепція формування комунікативнориторичних умінь у майбутніх фахівців у галузі англійської філології. Елементи комунікативнориторичної підготовки цілісно не об'єднані, вони здебільшого випадкові, частково зафіксовані в окремих освітніх дисциплінах, які вивчаються 
студентами на бакалавраті, понад те, компонент комунікативної культури, зокрема, комунікативнориторичні вміння, розглядаються як другорядні, перебувають на задньому плані професійної підготовки майбутніх учителів англійської мови, отже, не є предметом особливої уваги теоретиків і практиків.

У теорії педагогічної освіти і науки нині склалася ситуація, коли мовна підготовка особистості розглядається ученими радше як переважно теоретична, що спрямована на забезпечення певної системи знань із цієї дисципліни. Ми вважаємо, що нова парадигма української вищої педагогічної освіти ставить перед освітянами важливі завдання посилення практичної підготовки майбутніх учителів англійської мови, що, окрім певного запасу теоретичних знань у ділянці мови, володіють необхідними вміннями їх ефективно застосовувати в повсякденній педагогічній діяльності, комунікативній практиці.

Тому метою викладання фахових дисциплін мовного циклу на факультеті іноземних мов Прикарпатського національного університету імені Василя Стефаника $\epsilon$ формування професійно-орієнтовної англомовної комунікативної компетентності у студентів, зокрема й майбутніх учителів англійської мови в середній школі, здійснення виховання, освіти і розвитку особистості студента у процесі навчання тощо. Основними завданнями вивчення фахових дисциплін, які забезпечує кафедра англійської філології, є: набуття студентами мовних, лінгвокраїнознавчих та культурологічних знань 3 дисциплін; подальший розвиток системи мовленнєвих умінь говоріння, читання, письма і аудіювання; формування соціокультурної компетентності шляхом поглиблення знань студентів про історію, культуру, побут, звичаї і традиції народу, мова якого вивчається; формування професійної компетентності шляхом залучення до виконання професійно-орієнтованих завдань; формування у студентів позитивного ставлення до оволодіння мовою і культурою англомовного світу; виховання і розвиток у студентів почуття самосвідомості; формування вміння міжособистісного спілкування, необхідного для повноцінного функціонування у навчальному та професійному середовищі тощо.

На прикладі навчальної дисципліни “Академічне публічне мовлення”, яка читається для бакалаврів, покажемо, як можливості цього навчального предмету для формування комунікативно-риторичних умінь майбутніх фахівців. Цей загальнотеоретичний курс має на меті забезпечити студентів систематичними знаннями основ сучасного публічного мовлення як науки про мисленнєво-мовну діяльність, спрямовану на переконання, вплив та досягнення цілей у процесі мовної комунікації; сформувати у студентів уміння і навички аналізувати та продукувати тексти різного типу відповідно до мети, призначення й умов спілкування; сформувати навички ефективної мовленнєвої поведінки в актуальних ситуаціях спілкування, виховати уважне і критичне ставлення до свого мовлення у всіх сферах спілкування. У результаті вивчення цієї навчальної дисципліни студент повинен уміти робити риторичний аналіз промов; створювати тексти публічних виступів академічного характеру, актуалізуючи набуті знання на кожному з етапів підготовки й виголошення промови; ефективно вести суперечки, використовуючи коректні прийоми тощо.

Отже, комунікативно-риторичну підготовку майбутніх фахівців умовно можна представити як синтез взаємопов'язаних складників мисленнєвого, мовленнєвого і комунікативного. Така структура, на нашу думку, уможливлює поєднати в комунікативно-риторичних уміннях класичні підходи до риторичної діяльності (класична тріада “думка - слово - дія”), і сучасні вимоги до іiі організації та здійснення. Вона, вважаємо, найбільш повно відображає їх сутність. Звісно, ми умовно виокремили ці компоненти, які взаємно пов'язані між собою, і увиразнюємо їх задля ї подальшого більш докладного вивчення й наукового розгляду.

Розглядаючи структуру комунікативнориторичної культури в сукупності трьох і1ї складників (мисленнєвого, мовленнєвого і комунікативного), провідними ми виокремлюємо всі три: мисленнєвий компонент, який працює на кожному етапі риторичної діяльності, та мовленнєвий компоненти, який розуміється нами як проміжний між мисленнєвим і комунікативним, що здійснює їх зв'язок і органічне поєднання в риторичній діяльності через дві провідні функції мовлення: першу функцію, у якій мовлення виступає інструментом мислення й носієм свідомості (сигніфікативна функція), і другу, у якій мовлення є засобом спілкування (комунікативна функція). Комунікативно-риторичні вміння в цій структурі є важливим інструментом організації практичної діяльності фахівця, для вчителя англійської мови ці вміння - професійно необхідні, позаяк його праця пов'язана зі спілкуванням та налагодженням ефективної взаємодії зі школярами, їхніми батьками, своїми колегами тощо. 


\section{КОМУНІКАТИВНО-РИТОРИЧНИЙ АСПЕКТ ПІДГОТОВКИ МАЙБУТНЬОГО ВЧИТЕЛЯ АНГЛЙСЬКОЇ МОВИ}

Науковці слушно визначають професійні завдання майбутнього педагога, ефективне забезпечення яких залежить і від ступеня володіння комунікативно-риторичними вміннями. Назвемо окремі із цих завдань: впливати на спілкування, взаємини між людьми, на ситуацію в мікросоціумі, стимулювати, спонукати учня до тієї чи іншої діяльності; будувати взаємини на основі діалогу тощо $[1 ; 3 ; 5]$, які актуалізують провідну роль комунікативної діяльності у професії вчителя, необхідність відповідної підготовки до неї студентів. Ми вважаємо, що комунікативні аспекти діяльності майбутнього вчителя англійської мови можна з повним правом назвати комунікативно-риторичними. Адже метою цієї діяльності $є$ не тільки встановлення зв'язків та передавання певної інформації, й позитивний вплив на особистість, досягнення взаєморозуміння, переконання, роз'яснення, спонукання засобами дієвого слова. А це вже аспекти риторичні, i вимагають від учителя застосування комунікативно-риторичних умінь: уміння формулювати цілі і завдання професійного спілкування; ставити запитання і професійно на них відповідати; управляти спілкуванням залежно від визначених цілей; доводити, аргументувати, спростовувати, переконувати; вести бесіду, співбесіду, ділову розмову, спір, дискусію, диспут, полеміку тощо; володіти технікою і логікою мовлення; а також відповідними мовленнєвими структурами і лексичними одиницями, що впливають на емоційно-експресивний стан учня та інші.

На часі процес риторизації професійної підготовки майбутніх учителів англійської мови, зокрема в частині обов'язкових предметів, забезпечення професійно-педагогічної спрямованості змісту навчання, активізації навчально-риторичної діяльності студентів, розширення практичної підготовки, формування комунікативнориторичних умінь в єдності мисленнєвого, мовленнєвого та комунікативного компонентів, організації ефективної самостійної роботи студентів, установленні міжпредметних зв'язків 3 іншими дисциплінами, які можуть сприяти формуванню та вдосконаленню цих умінь. Значні потенційні можливості щодо формування комунікативно-риторичних умінь у майбутніх фахівців має курс "Українська мова за професійним спрямуванням”, “Педагогіка", “Філософія" та ін.

Висновки та перспективи подальших досліджень. Формування комунікативнориторичних умінь майбутнього вчителя англійської мови в системі вищої освіти $є$ вагомим резервом

Молодь і ринок №3 (189), 2021 підвищення якості підготовки спеціалістів. адже без уміння вести конструктивний діалог, диспут, бесіду, виступати 3 промовою, висловлюючи власний погляд на проблему сучасності, руйнується педагогічне спілкування, гальмується демократизація шкільного й університетського життя. Комунікативно-риторичну культуру розглядаємо як інтегративну властивість особистості, що грунтується на відповідних знаннях і навичках та забезпечує готовність виконувати комунікативно-риторичну діяльність. У структурі комунікативно-риторичних умінь, що розглядається нами як своєрідне відображення структури комунікативно-риторичної культури, виокремлюємо три взаємопов'язаних компоненти (мисленнєвий, мовленнєвий, комунікативний). Вимоги професії майбутнього вчителя англійської мови передбачають наявність у фахівця відповідних умінь для ефективного забезпечення іiї комунікативно-риторичних аспектів. Риторичні вміння вчителя англійської мови мають свою специфіку, що зумовлюється метою, завданнями, об'єктами, сферами застосування та функціями його професійної діяльності.

Подальшого вивчення потребує проблема аналізу та діагностики чинних змісту, форм і методів комунікативно-риторичної підготовки майбутніх учителів англійської мови в процесі їхнього навчання за умов бакалаврату, стану сформованості в них комунікативно-риторичних умінь.

\section{ЛІТЕРАТУРА}

1. Білавич Г., Мукан Н. Культура українського мовлення майбутніх правознавців крізь вимір еристики. Молодь і ринок. 2020. № 6-7 (185-186). С. 47-51.

2. Загальноєвропейські Рекомендації з мовної освіти: вивчення, викладання, оцінювання наук. ред. укр видання д-р пед. наук, проф. С.Ю. Ніколаєва. Київ: Ленвіт, 2003. 273 c.

3. Калініна Л. В., Самойлюкевич І. В. Професійна підготовка майбутнього вчителя іноземних мов у контексті європейських вимог. 2014. URL: http:// eprints.zu.edu.ua/481/1/04klvkev.pdf

4. Концепція реалізації державної політики у сфері реформування загальної середньої освіти "Нова українська школа" на період до 2029 року. URL: https:/ /osvita.ua/legislation/Ser osv/54258/

5. Ніколаєва С. Ю. Цілі навчання іноземних мов в аспекті компетентнісного підходу. Іноземні мови. 2010. № 2. C. 11-17.

6. The European Indicator of Language Competence. Report from the Educational Council to the European Council. Barcelona, March 2002. URL: http:// www.edu.language learning.com.ua.

\section{REFRERENCES}

1. Bilavych, H., Mukan, N. (2020). Kultura ukrainskoho 


\section{ЛІТЕРАТУРА ЯК ЗАСІБ ФОРМУВАННЯ НАЦІОНАЛЬНОӦ СВІДОМОСТІ ТА ХАРАКТЕРУ ОСОБИСТОСТІ КРІЗЬ ПРИЗМУ ТВОРЧОСТІ БОГДАНАЛЕПКОГО}

movlennia maibutnikh pravoznavtsiv kriz vymir erystyky [The ukrainian speech culture of future jurists through the prism of heuristics]. Youth \& market, no. 6-7 (185186), pp. 47-51. [in Ukrainian].

2. Zahalnoievropeiski Rekomendatsii z movnoi osvity: vyvchennia, vykladannia, otsiniuvannia (2003). [PanEuropean Recommendations for language education: study, teaching, assessment]. (Ed.). S.Iu. Nikolaieva. Kyiv. [in Ukrainian].

3. Kalinina, L. V. \& Samoiliukevych, I. V. (2014). Profesiina pidhotovka maibutnoho vchytelia inozemnykh mov u konteksti yevropeiskykh vymoh [Professional training of future teachers of foreign languages in the context of European requirements.]. Available at: http:// eprints.zu.edu.ua/481/1/04klvkev.pdf [in Ukrainian].
4. Kontseptsiia realizatsii derzhavnoi polityky u sferi reformuvannia zahalnoi serednoi osvity "Nova ukrainska shkola" na period do $2029 \mathrm{roku}$ [The concept of implementation of state policy in the field of reforming general secondary education "New Ukrainian School" for the period up to 2029]. Available at: https://osvita.ua/legislation/Ser_osv/54258/[in Ukrainian].

5. Nikolaieva, S. Yu. (2010). Tsili navchannia inozemnykh mov v aspekti kompetentnisnoho pidkhodu [The goals of teaching foreign languages in terms of the competence approach]. Foreign languages, no.2, pp. 1117. [in Ukrainian].

6. The European Indicator of Language Competence. Report from the Educational Council to the European Council. Barcelona, March 2002. Available at: http:// www.edu.language learning.com.ua. [in English].

Стаття надійшла до редакції 15.02.2021

УДК: 37.035.6:371

DOI:

Марія Багрій, кандидат філологічних наук, викладач вищої категорії Івано-Франківського фахового коледжу ДВНЗ "Прикарпатський національний університет імені Василя Стефаника" Світлана Довбенко, кандидат педагогічних наук, дочент кафедри педагогіки початкової освіти ДВНЗ "Прикарпатський національний університет імені Василя Стефаника"

\section{ЛІТЕРАТУРА ЯК ЗАСІБ ФОРМУВАННЯ НАЦІОНАЛЬНОЇ СВІДОМОСТІ ТА ХАРАКТЕРУ ОСОБИСТОСТІ КРІЗЬ ПРИЗМУ ТВОРЧОСТІ БОГДАНА ЛЕПКОГО}

Стаття присвячена проблемі дослідження літератури як засобу формування національної свідомості та характеру особистості крізь призму творчості Богдана Лепкого. Саме за иьього періоду в українській історико-педагогічній думиі, в освітній практиці нагромаджено значний пласт науково-теоретичних розробок, успішно реалізовано низку проєктів, які варто із позицій сьогодення глибоко вивчити й проаналізувати, творчо застосовувати з урахуванням конкретної освітньо-педагогічної ситуачії.

Ключові слова: національна свідомість; Богдан Лепкий; характер; особистість; украӥнська лimepamypa.

תim. 7.

Mariya Bahriy, Ph.D.(Philology), Lecturer of the highest category of Ivano-Frankivsk Vocational College SHEI "Vasyl Stefanyk Precarpathian National University" Svitlana Dovbenko, Ph.D.(Pedagogy), Associate Professor of the Pedagogy of Primary Education Department, SHEI "Vasyl Stefanyk Precarpathian National University"

\section{LITERATURE AS A MEANS OF FORMATION OF NATIONAL CONSCIOUSNESS AND THE NATURE OF PERSONALITY THROUGH THE PRISM OF THE CREATIVITY OF BOHDAN LEPKIY}

The article is devoted to the problem of formation of national consciousness and character of personality through the prism of Bohdan Lepkiy's work. It was during this period in the Ukrainian historical and pedagogical thought, in educational practice accumulated a significant layer of scientific and theoretical developments, successfully implemented a number of projects that should be deeply analyzed from today's standpoint, creatively applied taking into account the specific educational and pedagogical situation.

B. Lepkiy with his historical novels, in particular the pentalogy of "Mazepa", public and patriotic lyrics contributed to the formation of patriotism, citizenship, the establishment of the state idea in the minds of children, youth and adults; rehabilitation of the figure of Ivan Mazepa initiates the cult of Mazepa as a national hero of Ukraine, which was a revolutionary step, as well as a literary sensation in the artistic space. This is how the educational ideal is expressed in Bohdan Lepkiy's work - the formation of children and youth as nationally conscious 